\title{
Selected physical medicine interventions in the treatment of diabetic foot syndrome
}

\author{
Kamila Gebala-Prajsnar', Agata Stanek', Jaroslaw Pasek ${ }^{1,2}$, Grzegorz Prajsnar ${ }^{3}$, \\ Andrzej Berszakiewicz', Aleksander Sieron', Armand Cholewka ${ }^{4}$ \\ 'Department of Internal Medicine, Angiology and Physical Medicine, School of Medicine with the Division of Dentistry \\ in Zabrze, Medical University of Silesia, Bytom, Poland \\ ${ }^{2}$ Institute of Physical Education, Tourism and Physiotherapy, Jan Dlugosz University of Czestochowa, Poland \\ ${ }^{3}$ Dr Janusz Daab Independent Public Regional Hospital of Trauma Surgery, Piekary Slaskie, Poland \\ ${ }^{4}$ Department of Medical Physics, Chelkowski Institute of Physics, University of Silesia, Katowice, Poland
}

\begin{abstract}
The diabetic foot syndrome (DFS) is among chronic complications of diabetes mellitus; it can affect individuals with both type I and type 2 diabetes. Diabetic patients have up to a 25\% lifetime risk of developing DFS, which is both a medical and social problem. Several studies have indicated that, apart from pharmacotherapy and modern active wound dressings, physical medicine also has a role in prevention and management of diabetic foot ulcers. The paper presents physical medicine interventions most recognized in the conservative management of DFS.
\end{abstract}

Key words: physical medicine, diabetic foot syndrome; magnetotherapy, magnetostimulation, laser therapy, hyperbaric oxygen therapy, oxybaria $\mathrm{S}$ therapy, negative pressure wound therapy

Acta Angiol 20I5; 21 , 4: 140-145

\section{Introduction}

The United Nations Organization recognized diabetes, a non-infectious disease, as an epidemic of the $2 I^{\text {st }}$ century [ $\left.I\right]$. In 2012, diabetes was diagnosed in 371 million people worldwide, and it has been estimated the number will increase to 552 million in 2030. In Poland diabetes affects 3 million people, I million of whom are undiagnosed [2]. The diabetic foot syndrome (DFS) is among chronic complications of diabetes mellitus; it can affect individuals with both type $\mathrm{I}$ and type 2 diabetes. Diabetic patients have up to a $25 \%$ lifetime risk of developing DFS [3].

The diabetic foot syndrome is characterized by the presence of infection and/or ulcer, and/or deep tissue destruction as a result of underlying neuropathy and different severity ischaemia from peripheral vascular disease [4].
DFS involves lesions to blood vessels, nerves, skin and bones. The key factors implicated in the development of foot ulceration are diabetic neuropathy, macroand microangiopathy, foot deformity, microinjuries and infection [5].

The most devastating complication of DFS is lower limb amputation frequently causing disability. It is estimated that $5 \%$ to $15 \%$ of patients with foot ulcers will require an amputation, with major lower limb amputations accounting for $50 \%$ of these amputations. Over $50 \%$ of the amputees will undergo another amputation within 5 years, of whom $50 \%$ will not survive the next 5 years [6].

In the years 2009-2012, the rate of major nontraumatic lower limb amputations has increased from 9.7I \pm 1.92 to $11.96 \pm 1.88$ per 100,000 Polish population. It should also be emphasized that, in that time period, 
every other major nontraumatic amputation in Poland was performed in diabetic patients [7].

Hence, DFS is both a medical and social problem. Several studies have indicated that, apart from pharmacotherapy and modern active wound dressings, physical medicine also has a role in prevention and management of diabetic foot ulcers. The paper presents physical medicine interventions most recognized in the conservative management of DFS.

\section{Magnetic field (magnetotherapy and magnetostimulation)}

Magnetotherapy and magnetostimulation are physical medicine therapies based on electromagnetic induction consisting of the production of an electromotive force in a conductor exposed to a time varying magnetic field. Depending on the magnetic field strength (magnitude), two types of intervention can be distinguished, i.e., magnetotherapy (over $100 \mu \mathrm{T}$ ) and magnetostimulation (below $100 \mu \mathrm{T}$ ). According to the criteria of physical medicine, the magnetic field used for magnetic therapy has a frequency below 100 $\mathrm{Hz}$ with induction of $0.1-30 \mathrm{mT}$, while electromagnetic fields of magnetostimulation have a frequency range of $\mathrm{I}-3000 \mathrm{~Hz}$ and magnetic flux density between I pT and $100 \mu \mathrm{T}[8]$.

At the cellular level, magnetic fields act to accelerate electrolyte exchange between the cell and its surroundings, increase mitotic activity, have antimutagenic effects, increase enzyme activity and ATP and DNA synthesis. At the tissue level, magnetic fields beneficially affect peripheral and microcirculation, enhance angiogenesis and improve the function as well as irritability of nerve fibres [9]. Irrespective of electromagnetic field effect on human tissues, it has been used to enhance cell respiration, vasodilation, angiogenesis, soft tissue regeneration; it also exhibits anti-inflammatory, anti-oedematous and analgetic actions in the treatment of diabetic foot [10]. Magnetic field does not exert noticeable adverse effects. Contraindications include pregnancy, neoplastic disease and active tuberculosis [ $\mathrm{II}$.

Several researchers [12, 13] demonstrated beneficial effects of pulsed electromagnetic fields on wound healing in streptozotocin-induced diabetic rats; also, wound tensile strength was greater in animals exposed to extremely low frequency pulsed electromagnetic field which was associated with a local increase in myofibroblasts. Cultured medium from human umbilical vein endothelial cells exposed to pulsed electromagnetic fields exhibited a noticeable increase in FGF-2 expression. Local application of the medium to skin flaps created on streptozocin-induced diabetic mice facilitated wound healing and increased its tensile strength. Pulsed electromagnetic fields were also found to prevent ischaemia-associated necrosis [14].

A study on Wistar rats [15] with streptozotocin-induced diabetes mellitus revealed that repetitive pulsed magnetic field $(50 \mathrm{~Hz}, 5 \mathrm{mT})$ ameliorated the diabetes-induced macroangiopathy. Diabetic rats treated with pulsed magnetic field showed an increase in thoracic aorta relaxation response to acetylcholine and reduced contraction response to phenylephrine compared to the diabetic but non-exposure group.

Diabetic neuropathy is a complication which is far more difficult for pre-clinical studies due to the need for endpoint selection. A study on adult male Sprague-Dawley rats with streptozotocin-induced diabetes [16] exposed to $15 \mathrm{~Hz}$ pulsed electromagnetic field demonstrated increased hind paw withdrawal threshold to mechanical and thermal stimuli, lesser extent of demyelination and axon enlargement and less vascular endothelial growth factor (VEGF) immunostaining intensity compared to the diabetes mellitus with sham pulsed magnetic field exposure group. Thus, it can be concluded that pulsed magnetic field prevents the progression of diabetic neuropathy.

The effects of pulsed electromagnetic field were also studied in diabetic patients. Kwan et al. [17] exposed patients with diabetic foot ulcers to pulsed electromagnetic field ( $12 \mathrm{~Hz} ; \mathrm{I} .2 \mathrm{mT})$ and revealed an increase in peripheral microcirculation velocity and wound healing acceleration compared with the control group.

Musaev et al. [18] demonstrated beneficial effects of pulsed electromagnetic field $(10 \mathrm{~Hz})$ in the initial stages of diabetic polyneuropathy as well as in patients with diabetes mellitus of less than 10 years' duration; the conductivity of peripheral sensory and motor nerves was found to have improved.

In a study conducted in 16 American academic and clinical centres [19], low-frequency pulsed electromagnetic fields were applied onto the feet of patients with stage 2 or 3 diabetic polyneuropathy. Patients exposed to pulsed electromagnetic field exhibited a trend toward reductions in diabetic polyneuropathy symptoms on the Patient's Global Impression of Change scale (PGIC) as well as increased epidermal nerve fibre density which was significantly correlated with decreases in analogue pain scores.

Wróbel et al. [20], on the other hand, concluded that genuine magnetic field exposure had no advantage over sham exposure in reducing pain intensity, improving quality of life and decreasing sleep disturbances and glycated haemoglobin concentrations.

\section{Hyperbaric oxygen therapy}

Hyperbaric oxygen therapy (HBOT) is providing the body with $100 \%$ oxygen delivered at 2.5 times 
normal atmospheric pressure. The most important benefits include increased oxygenation of hypoxic and ischaemic tissues, wound healing acceleration, significant reduction of oedema, circulation improvement, immunity enhancement as well as bacteriocidal and bacteriostatic actions. HBOT also enhances white blood cell proteolysis of necrotic tissues, fibroblast proliferation, bone remodelling along with osteoblastic and osteoclastic activity, angiogenesis, epithelial cell migration and collagen deposition and cross-linking. Hyperbaric therapy is given in a total body chamber. The only absolute contraindication of hyperbaric oxygen therapy is an untreated pneumothorax. The relative contraindications include upper respiratory infections, history of thoracic or ear surgery, emphysema with $\mathrm{CO}_{2}$ retention, pregnancy, claustrophobia, low threshold for seizures and bleomycin therapy [21, 22].

An analysis of seven randomized clinical trials conducted in the years 1992-2013 to assess the value of HBOT in a total of 376 patients demonstrated some effectiveness of the therapy in promoting the healing of diabetic foot ulcers and preventing amputations [23]. However, clinical studies on the use of hyperbaric oxygen in conservative treatment of diabetic foot have not yet resulted in a clinical application at the practitioner level. Huang et al. recommend HBOT in patients with Wagner Grade $\geq 3$ diabetic foot ulcers who had recently undergone surgical debridement as well as in Wagner Grade $\geq 3$ diabetic foot ulcers that do not heal within 30 days of surgical debridement; in these patients hyperbaric oxygen seems to promote wound healing and prevent amputation. There is no adequate evidence to justify the use of HBOT in patients with Grade $\leq 2$ diabetic foot ulcers [24].

A retrospective study of Akgul et al. [25] revealed that ischaemic heart disease, stroke, proliferative and nonproliferative retinopathy had an adverse effect on HBOT results in patients with DFS. Average scores of peripheral arterial disease at femoral level affected HBOT results more negatively than single arterial scores and average scores at popliteal and pedal levels. However, the diabetic lower extremity wound response to $\mathrm{HBO} 2$ therapy was unaffected by glycaemic control prior to treatment. After 20 HBOT sessions carried out over 30 days, no differences were noted between patients with $\mathrm{HbA}_{\mathrm{Ic}}<7.5 \%$ and $\geq 7.5 \%$ regarding ulcer surface area and depth. Hence, HBOT should not be delayed due to suboptimal blood glucose control [26].

Exposure of murine diabetic wounds to hyperbaric oxygen [27] stabilized and activated the hypoxia-inducible factor I (HIF-I), which is known to promote cell proliferation in a healing wound.

HBOT has also been noted to reduce the risk of QTc interval prolongation which protects against life-threaten- ing arrhythmias. After a 2-year follow-up, QTc time was significantly shorter in the HBOT group, whose members had received 40 treatment sessions at 2.5 ATA, compared with the placebo group [28].

Fife et al. [29] reported outcomes in a large number of patients who had received hyperbaric oxygen therapy for diabetic low-extremity ulcers. The authors concluded that hyperbaric oxygen treatment should be an important adjunctive therapy to heal lower-extremity lesions, especially those with a Wagner grade of 3 or higher.

\section{Ozone therapy}

Ozone exhibits bactericidal, virucidal and fungicidal properties; it promotes granulation, enhances wound epidermis formation, local tissue oxygen saturation and eliminates odour associated with chronic wounds. The efficacy of ozone therapy stems from the fact of most microorganisms being sensitive to ozone exposure. Medical ozone is actually a mixture of $5 \%$ maximum ozone and $95 \%$ oxygen. Contraindications to ozone therapy include untreated hyperthyroidism, recent myocardial infarction, uncontrolled hypertension and alcohol intoxication [30].

Martinez-Sanchez et al. [3I] compared the therapeutic efficacy of ozone and antibiotic therapy in the treatment of diabetic foot syndrome. Ozone treatment improved glycaemic control, reduced oxidative stress and promoted the healing process thus reducing the number of amputations compared with the control group on antibiotic therapy. No side effects were observed.

In another study [32], patients with diabetes mellitus complicated by lower limb angiopathy and diabetic retinopathy were evaluated for the efficacy of external, systemic (intravenous or rectal) or combined techniques of ozone-oxygen administration. The external administration proved superior in the treatment of lower limb ulceration whereas the systemic and combined methods produced better effects with respect to retinopathy and biochemical parameters.

\section{OXYBARIA S}

OXYBARIA S is a novel portable and reusable system for simultaneous hyperbaric oxygen and ozone therapy of chronic wounds. The combination of the two methods improves local tissue oxygenation thereby accelerating chronic wound healing. Bactericidal action promotes wound cleanliness, which also has a beneficial effect on the healing process [33].

The method was developed by professor Aleksander Sieroń, Department of Internal Diseases, Angiology 
and Physical Medicine, Medical University of Silesia. It won a Grand Prix award at the $63^{\text {rd }}$ International Exhibition on Inventions, Research and New Technologies BRUSSELS INNOVA in 20I4. The applied ozone concentration of $20 \mathrm{mg} / \mathrm{cm}^{3}$ is reached after 5 minutes of the generator's work. The system is also equipped with an ozone neutralizer. The recommended ozone flow rate ranges from $5-8 \mathrm{l} /$ minute. The device is self-contained and portable which makes it easy to use not only in hospitals but also family doctors' offices or in the patient's home. Hence, the cost of treatment is reduced [33]. A double-blind, randomized clinical trial conducted in diabetic patients with a Wagner classification stage 2 or 3 ulcer or a stage 4 ulcer after surgical debridement, all treated for at least 12 weeks with oxygen-ozone combination, revealed a significantly higher rate of complete wound closure compared to sham-treated participants [34]. Among ozone-oxygen subjects with wound size $\leq 5 \mathrm{~cm}$, the rate of total wound closure was $100 \%$.

The efficacy of oxygen-ozone treatment of diabetic foot ulcers was also confirmed by Zhang et al. [35]. Wound size was significantly reduced in the oxygen-ozone group (plus standard therapy) compared with the control (standard therapy only). Following the treatment, local expression of growth factors involved in wound healing, i.e., vascular endothelial growth factor (VEGF), transforming growth factor beta (TGF- $\beta$ ) and platelet-derived growth factor (PDGF) was significantly higher in the oxygen-ozone group.

\section{Laser therapy}

Laser emits light through the amplification based on the stimulated emission of electromagnetic radiation. Lasers are divided into groups according to different criteria, e.g., the state of matter of the active medium (solid, liquid, gas, plasma), spectral range of the laser wavelength (visible spectrum, ultra-violet spectrum, infra-red spectrum) or energy level (high, medium and low energy). High power lasers are used in surgical dermatology, eye surgery and neurosurgery. Physical medicine typically uses lower energy lasers that do not have a thermal effect on tissue; however, there have been more and more reports on the application of high energy lasers. Upon reaching a tissue, laser radiation is reflected or absorbed and dissipated. Effective absorbers of the light include melanin, aromatic amino acids (tyrosine, tryptophan), water, blood and haemoglobin. Collagen of the basal layer controls light dissipation (especially that of shortwave light). Depending on the angle of light incidence and surface structure, 40-50\% of radiation may be reflected. While planning laser therapy, it should be remembered that effective penetration depth in the tissue is proportional to wavelength, i.e., infrared light has the deepest tissue penetration. Biological effects of laser therapy are not caused by body temperature elevation, since the latter only increases by $0.1-I^{\circ} \mathrm{C}$. It is the interaction between the tissue and electromagnetic radiation that results in oxygen intake, regeneration processes and cell proliferation enhancement, vessel dilation, anti-inflammatory and anti-oedematous effects, a decrease in the conductive properties of nociceptive afferents and a change in the activity of serotonergic synapses due to an increase in beta-endorphin levels. There are no absolute contraindications to laser therapy but caution should be taken in pregnant women, patients with active neoplastic disease, severe infections, electronic implants and those on photosensitizing medications [8, 36].

Laser wavelength of $632.8 \mathrm{~nm}$ (visible range) has been found to produce the most beneficial effects with respect to the migration, viability and proliferation of diabetic wounded and unwounded human skin fibroblasts WSI ) [37]. However, a choice of irradiation dose still remains a problem. In an in vitro study on wounded human skin fibroblasts, heliumneon laser irradiation in a single dose of $5 \mathrm{~J} / \mathrm{cm}^{2}$ and two or three doses of $2.5 \mathrm{~J} / \mathrm{cm}^{2}$ had a stimulatory effect on wounded fibroblasts with an increase in cell migration and cell proliferation. Multiple exposure to $16 \mathrm{~J} / \mathrm{cm}^{2}$ inhibited cell proliferation (healing) and caused damage to wounded cells [38].

Pal et al. [39] found that the total energy dose had greater influence on cellular proliferation and the kinetics of reactive oxygen species generation than did laser intensity.

Low-intensity laser irradiation also increased collagen type I content, cell migration, proliferation and viability in diabetic wounded fibroblasts [40].

The efficacy of laser therapy in the treatment of diabetic foot syndrome was also studied in clinical settings.

Kajagar et al. [4I] studied patients with type 2 diabetes mellitus and foot ulcers; they observed that a group with conventional and low level laser therapy had a significant reduction in ulcer area compared with patients on conventional therapy only. A double-blind clinical trial [42] also confirmed accelerated reduction of ulcer size and larger number of patients with complete healing in the group who received laser therapy. Heliumneon and infra-red laser therapy of diabetes-related skin lesions improved blood flow parameters compared with patients who had only received conventional treatment [43].

\section{Negative Pressure Wound Therapy}

Negative Pressure Wound Therapy (NPWT) is a therapeutic technique consisting of the application 
of negative pressure $(125 \mathrm{~mm} \mathrm{Hg})$ to the wound bed. NPWT accelerates wound healing by stimulating the formation of granulation tissue as well as fibroblast and endothelial cells proliferation, elimination of excess exudate from wound surface, reduction of periwound oedema, improvement of blood supply to wound bed, maintenance of adequate wound humidity and reduction of the microorganism burden on the wound surface $[44,45]$. The therapy is particularly useful in patients with excess wound exudate but should not be applied in those with high risk for prolonged bleeding (e.g., taking anticoagulant medications) [5].

In patients with type 2 diabetes mellitus, NPWT significantly reduced the size and/or accelerated healing of ulcers in patients with mixed and neuropathic origin diabetic foot syndrome [46]. Sajid et al. [47] observed that NPWT using assisted wound closure was more effective than advanced moist wound therapy in the management of diabetic foot ulcers.

\section{Conclusions}

There has been an increasing number of Polish and international reports on the efficacy of physical medicine interventions, including electromagnetic fields, hyperbaric oxygen therapy, low energy lasers or negative pressure wound therapy, which all have been used as adjuncts to conventional therapies for diabetic foot ulcers. Thanks to modern technology, therapy devices are now smaller, lighter, more user-friendly and cheaper. Consequently, the therapies have become more available, not only in specialist hospital departments but also at outpatient clinics or even in the patient's home. It should be emphasized that the interventions appear to be safe for use with very few contraindications.

\section{References}

I. Resolution adopted by the General Assembly, 61/225, 20 December 2006. http://www.un.org/ga/search/view_doc.asp?symbol $=\mathrm{A} / \mathrm{RES} / 6 \mathrm{I} / 225 \&$ Lang $=\mathrm{E}$.

2. Cukrzyca: Ukryta pandemia. Sytuacja w Polsce. Raport. Edycja 2013. http://www.stopacukrzycowa.com/cukrzyca_ukryta_pandemia_polska_raport_2013.pdf.

3. Boulton AJ, Vileikkyte L, Ragnarson-Tennvall G, Apelqvist J (2005) The global burden of diabetic foot disease. Lancet; 12: 1719-1724.

4. Alberti KG, Zimmet PZ (1998) Definition, diagnosis and classification of diabetes mellitus and its complications. Part I: diagnosis and classification of diabetes mellitus. Provisional report of a WHO Consultation. Diabet Med; 15: 539-553.

5. Karnafel W (2014) Zespół stopy cukrzycowej. PZWL, Warszawa.

6. Armstrong DG, Lavery LA (2005). Clinical care of the diabetic foot. American Diabetes Association.

7. Czeleko T, Śliwczyński A, Nawrot I, Karnafel W (2014) Występowanie dużych nieurazowych amputacji kończyn dolnych osób bez cukrzycy w Polsce w latach 2009-2012 na podstawie bazy danych narodowego Funduszu Zdrowia. Acta Angiol; 20: |24-|3|.

8. Sieroń A, Cieślar G, Stanek A (2013) Pola magnetyczne i światło w medycynie i fizjoterapii. Wydawnictwo Alfa-Medica Press, Bielsko-Biała.

9. Sieroń A, Mucha R, Pasek J (2006) Magnetoterapia. Rehabil Prakt; 3: 29-32.

10. Jędrzejewski P, Cieślik T, Sieroń A, Przybylek K, Przybylek B (200I) Oddziaływanie wolnozmiennych pól magnetycznych na tkanki żywe. Inż. Biomat; 17-19: 30-31.

II. Jędrzejewski P, Cieślik T, Sieroń A (2002) Zastosowanie kliniczne wolnozmiennych pól magnetycznych — doświadczenia własne. Dent Med Probl; 39: 195-197.

12. Goudarzi I, Hajizadeh S, Salmani ME, Abrari K (2010) Pulsed electromagnetic fields accelerate wound healing in the skin of diabetic rats. Bioelectromagnetics; 31: 318-323.

13. Cheing GL, Li X, Huang L, Kwan RL, Cheung KK (20/4) Pulsed electromagnetic fields (PEMF) promote early wound healing and myofibroblast proliferation in diabetic rats. Bioelectromagnetics; 35: $161-169$.

14. Callaghan MJ, Chang El, Seiser $\mathrm{N}$ et al (2008) Pulsed electromagnetic fields accelerate normal and diabetic wound healing by increasing endogenous FGF-2 release. Plast Reconstr Surg; 121: |30-|4|.

15. Kavak S, Emre M, Meral I, Unlugenc H, Pelit A, Demirkazik A (2009) Repetitive $50 \mathrm{~Hz}$ pulsed electromagnetic field ameliorates the diabetes-induced impairments in the relaxation response of rat thoracic aorta rings. Int J Radiat Biol; 85: 672-679.

16. Lei T, Jing D, Xie K et al (2013) Therapeutic effects of $15 \mathrm{~Hz}$ pulsed electromagnetic field on diabetic peripheral neuropathy in streptozotocin-treated rats. PLoS One; 8: e6/414.

17. Kwan RL, Wong WC, Yip SL, Chan KL, Zheng YP, Cheing GL (2015) Pulsed electromagnetic field therapy promotes healing and microcirculation of chronic diabetes foot ulcers: a pilot study. Adv Skin Wound Care; 28: 212-219.

18. Musaev AV, Guseinova SG, Imamverdieva SS (2003) The use of pulsed electromagnetic fields with complex modulation in the treatment of patients with diabetic polyneuropathy. Neurosci Behav Physiol; 33: 745-752.

19. Weintraub MI, Herrmann DN, Smith AG, Backonija MM, Cole SP (2009) Pulsed electromagnetic fields to reduce diabetic neuropathic pain and stimulate neuronal repair: a randomised controlled study. Arch Phys Med Rehabil; 90: I 102-1 109.

20. Wróbel MP, Szymborska-Kajanek A, Wystrychowski G et al (2008) Impact of low-frequency pulsed magnetic fields on pain intensity, quality of life and sleep disturbances in patients with painful diabetic polyneuropathy. Diabetes Metab; 34: 349-354.

21. Kindwall EP, Whelan HT (1999) Hyperbaric medicine practice. Flagstaff, AZ: Best Publishing Company.

22. Sieroń A, Cieślar G, Kawecki M (2007) Zarys medycyny hiperbarycznej. Wydawnictwo Alfa-Medica Press, Bielsko-Biała.

23. Stoekenbroek RM, Santema TB, Legemate DA, Ubbink DT, van der Brink A, Koelemay MJ (2014) Hyperbaric oxygen for the treatment of diabetic foot ulcers: a systematic review. Eur J Vasc Endovasc Surg; 47: 647-655.

24. Huang ET, Mansouri J, Murad MH et al (2015) UHMS CPG Oversight Committee A clinical practice guideline for the use of hyperbaric oxygen therapy in the treatment of diabetic foot ulcers. Undersea Hyperb Med; 42: 205-247. 
25. Akgül EA, Karakaya J, Aydin S (20/4) Role of comorbidities as limiting factors to the effect of hyperbaric oxygen in diabetic foot patients: a retrospective analysis. Diabetes Ther; 5: 535-544.

26. Bahktiani P, Mansuri O, Yadav A et al (2015) Impact of hyperbaric oxygen on diabetic ulcers is unaffected by glycaemic control. Undersea Hyperb Med; 42: 183-190.

27. Sunkari VG, Lind F, Botusan IR et al (2015) Hyperbaric oxygen therapy activates hypoxia-inducible factor I (HIF-I), which contributes to improved wound healing in diabetic mice. Wound Repair Regen; 23: 98-103.

28. Fagher K, Katzman P, Löndahl M (2015) Hyperbaric oxygen therapy reduces the risk of QTc interval prolongation in patient with diabetes and hard-to-heal foot ulcers. J Diabetes Complications; 29: II98-1202.

29. Fife CE, Buyukcakir C, Otto G, Sheffield P, Love T, Warriner R (2007) Factors influencing the outcome of lower-extremity diabetic ulcers treated with hyperbaric oxygen therapy. Wound Repair Regen; 15: 322-331.

30. Antoszewski Z, Madej P (2007) Ozonoterapia i jej zastosowanie w medycynie. Wydawnictwo Alfa-Medica Press, Bielsko-Biała.

31. Martínez-Sánchez G, Al-Dalain SM, Menéndez S et al (2005) Therapeutic efficacy of ozone in patients with diabetic foot. Eur J Pharmacol; 523: 151-161.

32. Kulikov AG, Turova EA, Shcherbina TM, Kisileva OM (2002) Efficacy of different methods of ozone therapy in vascular complications of diabetes mellitus. Vopr Kurortol Fizioter Lech Fiz Kult; 5: 17-20.

33. Pasek J, Sieroń A (2015) OXYBARIA-S - nowatorskie urządzenie do hiperbarycznej terapii tlenowej. Rehabil Prakt; I: I-57.

34. Wainstein J, Feldbrin Z, Boaz M, Harman-Boehm I (201 I) Efficacy of ozone-oxygen therapy for the treatment of diabetic ulcers. Diabetes Technol Ther; 13: 1255-1260.

35. Zhang J, Guan M, Xie C, Luo X, Zhang Q, Xue Y (2014) Increased growth factors play a role in wound healing promoted by noninvasive oxygen-ozone therapy in diabetic patients with foot ulcers. Oxid Med Cell Longev; 2014: 273475

36. Sieroń A, Pasek J, Mucha R (2006) Lasery w medycynie i rehabilitacji. Rehabil Prakt; 2: 26-30.
37. Houreld N, Abrahamse $\mathrm{H}$ (2010) Low-intensity laser irradiation stimulates wound healing in diabetic wounded fibroblasts cells (WSI). Diabetes Technol Ther; 12: 97I-978.

38. Hawkins D, Abrahamse $H$ (2006) Effect of multiple exposures of low-level laser therapy on the cellular responses of wounded human skin fibroblasts. Photomed Surg; 24: 705-7।4.

39. Pal G, Dutta A, Mitra K et al (2007) Effect of low intensity laser interaction with human fibroblasts cells using fiber-optic nanoprobes. J Photochem Photobiol B; 86: 252-26I.

40. Ayuk SM, Houreld NN, Abrahamse H (2012) Collagen production in diabetic wounded fibroblasts in response to low-intensity laser irradiation $660 \mathrm{~nm}$. Diabetes Technol Ther; 14: III0-1 I I7.

4I. Kajagar BM, Godhi AS, Pandit A, Khatri S (20I2) Efficacy of low level laser therapy on wound healing in patients with chronic diabetic foot ulcers - a randomised control trial. Indian J Surg; 74: 359-363.

42. Kaviani A, Djavid GE, Ataie-Fashtami L et al (20II) A randomised clinical trial on the effect of low-level laser therapy on chronic diabetic foot wound healing: a preliminary report. Photomed Surg; 29: 109-II4.

43. Saied GM, Kamel RM, Labib AM, Said MT, Mohamed AZ (201 I) The diabetic foot and leg: combined He-Ne and infrared low-intensity lasers improve skin blood perfusion and prevent potential complications. A prospective study on 30 Egyptian patients. Lasers Med Sci; 26: 627-632.

44. European Wound Management Association (EWMA). Position Document: Topical negative pressure in wound management. London: MEP Ltd, 2007.

45. Nain PS, Uppal SK, Garg R, Bajaj K, Garg S (20II) Role of negative pressure wound therapy in healing of diabetic foot ulcers. J Surg Tech Case Rep; 3: 17-22.

46. Mrozikiewicz-Rakowska B, Kania J, Nowak A et al (2013) Wpływ terapii podciśnieniowej na redukcję wielkości owrzodzenia u chorych z cukrzycą typu 2 i zespołem stopy cukrzycowej typu neuropatycznego i mieszanego. Leczenie Ran; 10: 75-80.

47. Sajid MT, Ain Mustafa QU, Shaheen N, Hussain SM, Shukr I, Ahmed M (2015) Comparison of Negative Pressure Wound Therapy Using Vacuum-Assisted Closure with Advanced Moist Wound Therapy in the Treatment of Diabetic Foot Ulcers. J Coll Physicians Surg Pak; 25: 789-793. 
